\title{
The Problem of the Development of Dialogical Qualities of Cognitive Activity of Senior Pupils in the Educational Process
}

\section{Проблема розвитку діалогічних якостей пізнавальної діяльності старшокласників у навчальному процесі закладів середньої освіти}

\section{Eduard Ivashkevych}

Dr. in Psychology, Professor, Rivne State University of the Humanities, Rivne (Ukraine)

ORCID ID: https://orcid.org/0000-0003-0376-4615

Researcher ID: http://www.researcherid.com/rid/V-8872-2018

E-mail: ivashkevych.e@gmail.com

\section{Едуард Івашкевич}

Доктор психологічних наук, професор, Рівненський державний гуманітарний університет, м. Рівне (Україна)

\section{Olha Stoliarenko}

Ph.D. in Psychology, Assistant Professor, Kamianets-Podilskyi National Ivan Ohiienko University, Kamianets-Podilskyi (Ukraine)

ORCID ID: https://orcid.org/0000-0002-0479-574X

E-mail: stolyarenko.ob@gmail.com

\section{Ольга Столяренко}

Кандидат психологічних наук, доцент, Кам'янець-Подільський національний університет імені Івана Огієнка, м. Кам'янець-Подільський (Україна)

Address for correspondence, e-mail: kpnu_lab_ps@ukr.net Copyright: (C) Ivashkevych Eduard, Stoliarenko Olha

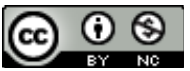
The article is licensed under CC BY-NC 4.0 International (https://creativecommons.org/licenses/by-nc/4.0/)

(C) Ivashkevych Eduard, Stoliarenko Olha

DOI (article): https://doi.org/10.32626/2227-6246.2021-53.126-148 
DOI: https://doi.org/10.32626/2227-6246.2021-53

2021. випУСК 53

The contribution of the author: Ivashkevych E. $-50 \%$, Stoliarenko O. $-50 \%$. Авторський внесок: Івашкевич Е. - 50\%, Столяренко О. - 50\%.

\section{ABSTRACT}

The purpose of article is: to describe the effectiveness of the proposed system of formative influences on the development of dialogical qualities of Cognitive Activity of senior pupils, which was determined on the basis of comparison of initial and final sections made by the method of semantic analysis of pupils' solutions of literary creative problems.

The following theoretical methods of the research were used to solve the tasks formulated in the article: a categorical method, structural and functional methods, the methods of the analysis, systematization, modeling, generalization. Also in our research we used empirical methods, such as the experiment of the effectiveness of group forms of the pupils' activity at the lessons.

The results of the research. We showed that the analysis of the problem situation is carried out only at the superficial level of the development of dialogical qualities of Cognitive Activity of senior pupils. Pupils analyze only the content of the proposed task, do not try to focus their own attention and the attention of other schoolchildren on the problems of this creative task. Therefore, the statements of pupils are purely superficial, and based on them it is impossible to draw conclusions about the problem and on this basis to identify the ways to solve the problem creatively. According to this, it is impossible to speak about the tolerant attitude to the opinions of partners of communication in the process of such a discussion, because the superficial nature of suggestions does not provide great opportunities for productive communication of senior pupils in order to solve different problems creatively.

According to the middle level of the development of dialogical qualities of Cognitive Activity of senior pupils in the educational process pupils explain and try to justify their own views according to proposed to them creative tasks, while actively cooperating with partners of communication, tried to be tolerant to other opinions and according to the proposed means of solving different problems. Senior pupils, analyzing their own statements and comparing them with the judgments of partners of communication, do not bring the process of solving a creative problem to a logical conclusion.

When we tell about a high level of the development of dialogical qualities of Cognitive Activity of senior pupils in the educational process pupils clearly

(C) Ivashkevych Eduard, Stoliarenko Olha DOI (article): https://doi.org/10.32626/2227-6246.2021-53.126-148 
justify their positions, analyzing their own points of view and statements, comparing them with the opinions of partners of communication. At the same time, schoolchildren show tolerance towards other pupils, even completely opposite statements and means of solving creative tasks by the last ones. Pupils actively defended their positions, logically explaining and justifying them. Schoolchildren do not object to cooperation with partners of communication in the process of solving problematic creative tasks within small micro-groups and the whole class.

Conclusions. It was proved that as the means of purposeful influence on the thinking abilities of pupils we considered solving cognitive tasks collected by schoolchildren into a special system.

We define thinking as the highest degree of Cognitive Activity of the person. We believe that the mental development of the child can not be analyzed separately from the mental development as a whole, from the interests of the child, his/her feelings, from personal traits and qualities. Mental development is a complex phenomenon, which is characterized by a set of features and due to a number of reasons: the content of knowledge acquired by the child, methods of influencing the personality. Until now, there is no unambiguous definition of "mental development». We believe that "mental development» is a complex dynamic system of quantitative and qualitative changes that occur in human mental activity in the connection with age and enrichment of life experience of pupils (in accordance with the socio-historical conditions in which schoolchildren live and according to individual characteristics of pupils' thinking).

Key words: dialogical qualities of Cognitive Activity, mental development, thinking abilities, creative tasks, the process of communication, productive communication, micro-groups, solving a creative problem, a logical conclusion.

\section{Introduction}

Cognitive activity is a relentless process of penetration of a human mind into the objective reality, the process of understanding psychological phenomena based on the disclosure of significant links with other phenomena of material reality, finding out the conditions under which it occurs, the reasons that give rise to it (Леонтьев, 1981; Михальчук \& Онуфрієва, 2020).

Cognitive activity is a process of understanding a new object, solving a certain cognitive task. This task is set up for (c) Ivashkevych Eduard, Stoliarenko Olha

DOI (article): https://doi.org/10.32626/2227-6246.2021-53.126-148 
pupils by each new educational material proposed by teacher for them (for example, a new descriptive or narrative text, the explanation of a certain natural phenomenon or social events, etc.) (Onufriieva, Chaikovska, Kobets, Pavelkiv \& Melnychuk, 2020). A need to understand a certain object actualizes the processes of understanding, awakens the opinions of pupils, gives them a certain purpose (Mykhalchuk \& Ivashkevych, 2018). In the processes of understanding there are the processes of thinking of the individual, which have the aim of revealing certain objects in their essential connections with other objects. As a result, understanding is the goal to which the work of human thought is directed.

The process of understanding primarily depends on the objective content of what students need to understand, the complexity of the connections they need to understand. At the same time, it depends on how the task is set before the students and how it is realized. The direction of the work of students' thought, the nature of those mental processes which are thus activated, depends on what question is arisen before them, what task they are aware of. Thus, in the same complex object, students' attention can be attracted by its various aspects (Zubiashvily, Kocharian, Lunov, Barinova \& Onufriieva, 2020).

The process of understanding also depends on the ways how the goal of understanding is combined with other goals which are arisen in the process of students' learning: whether it is a special task or means to solve other tasks (for example, tasks to remember, to recall, to imagine, to construct and etc.).

Based on this, scientists (Argyle, Furnh \& Graham, 1981) identify three aspects of cognitive activity: 1) a motivational aspect; 2) a semantic one; 3 ) the operating aspect.

As for the motivational side of cognitive activity, the important role is played on the teacher's ability to set by students the task to understand certain objects, to differentiate it from other tasks, in particular not to replace the goal of under-

(C) Ivashkevych Eduard, Stoliarenko Olha DOI (article): https://doi.org/10.32626/2227-6246.2021-53.126-148 
DOI: https://doi.org/10.32626/2227-6246.2021-53

2021. випуск 53

standing the task of simply way of memorizing the material (Емельянов, 1991; Куницына, 1995).

It is important to be able to determine exactly what the pupil needs to understand the material, what task to solve, as well as to set certain requirements for depth, completeness and clarity of understanding, bring them to the attention of pupils, gradually guide them from simple to complex mental tasks. Only in the presence of a properly understanding the goal by pupils can be caused and supported, and mental activity of pupils, in such a way, can lead to the desired result. Setting new and accessible cognitive tasks by pupils each time the teacher leads them from the phenomena to their ever deeper essence. Thus, setting new cognitive tasks for pupils is a necessary condition for the development of their ability to think.

It is clear that the ways in which pupils are brought to mind the task of understanding certain objects should vary depending on the nature of the material, age and training of pupils. Among them, one of the important ways to guide pupils' awareness of the mental tasks that are set before them in the school process is to answer clear, unambiguous, well-formulated questions to the teacher. It depends to a large extent on the teacher's question what exactly becomes the object of pupils' cognitive activity, which aspects of this object their attention amaze and what thought processes are directed to. Also, the questions have to be precise and definite, understandable to pupils.

The semantic side of cognitive activity must be effective (Cantor \& Kihlstrom, 1987). As a rule, in the process of studying, pupils learn ready-made concepts, historically developed by mankind and provided by school programs. However, learning new material should not be just a simple memorization. As a rule pupils' activity should be varied. In order to learn certain concepts pupils have to understand the objects that correspond to them, and this can only happen if they have a deal with the process of cognitive activity.

C Ivashkevych Eduard, Stoliarenko Olha

DOI (article): https://doi.org/10.32626/2227-6246.2021-53.126-148 
As for the operational side of cognitive activity, pupils master mental operations by themselves (Івашкевич \& Гудиma, 2020). Thus, the operational side of cognitive activity is characterized by the ability of pupils to understand objects and phenomena of objective reality. In the process of providing cognitive activity pupils master rational thinking techniques, learn to approach each object from different sides, study it comprehensively, prove their conclusions, learn to apply and test them in practice. The ability to think, to use thinking techniques are to develop them by themselves, as for students it is not only by setting formal and logical exercises, but also in the process of mental activity with the aim of mastering knowledge of various school subjects and properly to be guided by the teacher (Южанинова, 1984).

Thus, the same is the operational side of cognitive activity that provides many opportunities for the development of pupils' thinking.

So, the purpose of article is: to describe the effectiveness of the proposed system of formative influences on the development of dialogical qualities of Cognitive Activity of senior pupils, which was determined on the basis of comparison of initial and final sections made by the method of semantic analysis of pupils' solutions of literary creative problems.

\section{Methods of the research}

The following theoretical methods of the research were used to solve the tasks formulated in the article: a categorical method, structural and functional methods, the methods of the analysis, systematization, modeling, generalization. Also in our research we used empirical methods, such as the experiment of the effectiveness of group forms of the pupils' activity at the lessons.

We organized the experiment during 2020-2021 years. We formed experimental and control groups by the method of randomization (108 senior pupils):

(C) Ivashkevych Eduard, Stoliarenko Olha DOI (article): https://doi.org/10.32626/2227-6246.2021-53.126-148 
DOI: https://doi.org/10.32626/2227-6246.2021-53

2021. випуск 53

- experimental groups:

E1 (38 pupils) - 10-B form of secondary school № 20 .

E2 (27 pupils) - 9-A form of secondary school № 23.

- control groups:

C1 (35 pupils) - 10-A form of secondary school № 20.

C2 (38 pupils) - 9-B form of secondary school № 23.

\section{The results of the research}

This stage of the observational experiment has the aim of studying the functioning of a holistic system of dialogical qualities of cognitive activity of senior pupils in solving creative task by them. We determine that discursive creative thinking is a harmonious structure in the relationships of all its components. The study of the system of reflection was of particular importance as a mechanism for rethinking various kinds of stereotypes (intellectual, personal and communicative ones), which cause problem-conflict situations in pupils' process of communication with a novel, problem or creative task.

The effectiveness of the proposed system of formative influences on the development of dialogical qualities of Cognitive Activity of senior pupils was determined on the basis of comparison of initial and final sections made by the method of semantic analysis of pupils' solutions of literary creative problems. Thus, the development of dialogical qualities of Cognitive Activity was determined taking into account its motivational, semantic and operational aspects. The values of indicators that characterize the components of Cognitive Activity were calculated by formulas. For example, the meanings of the «monologue» component were defined in such a way:

$$
\mathrm{MV}=\frac{1}{\mathrm{~N}} \sum_{\mathrm{i}=1}^{\mathrm{n}} \mathrm{mv}_{\mathrm{i}} \times 100 \%
$$

where $\mathrm{MV}$ is the data of the indicator «a monologue statement» in $\% ; \mathrm{mv}_{\mathrm{i}}(\mathrm{i}=1,2, \ldots, \mathrm{n})$ is the number of incomplete (c) Ivashkevych Eduard, Stoliarenko Olha

DOI (article): https://doi.org/10.32626/2227-6246.2021-53.126-148 
monologue statements in the process of solving a creative task by the i-th pupil; $\mathrm{N}$ is the total number of all pupils' statements when they are solving the problem.

Similarly, the values of other indicators that characterize the components of Cognitive Activity were calculated.

In solving the creative task at the ascertaining stage of our research 238 senior pupils participated in two groups: group 1, which included 38 schoolchildren of the form E1 and 79 pupils of secondary school № 17, who also have studied World Literature in an increased volume; group 2, which included 38 pupils of the form C2 and 83 schoolchildren of secondary school № 2, who are taught according to the traditional program of studying World Literature.

Table 1

Protocol of recording the continuation of the story with a given beginning by a pupil Maryna V. in C2 form (the $1^{\text {st }}$ stage of the experiment)

\begin{tabular}{|c|l|}
\hline $\begin{array}{c}\text { Characteristics } \\
\text { of cognitive activity } \\
\text { by components }\end{array}$ & \multicolumn{1}{|c|}{ Protocol recording } \\
\hline \multicolumn{1}{|c|}{$\begin{array}{c}\text { Extraordinarily strange city } \\
\text { At the very edge of a dark, dense forest, } \\
\text { near a large golden field where wheat was } \\
\text { ripe, an anthill stood. It was inhabited by } \\
\text { large and small gray ants. All day hard- } \\
\text { working ants crawled through the woods, } \\
\text { looking for different branches to build their } \\
\text { homes and providing themselves with food. } \\
\text { Every day everything had been happened } \\
\text { again and again. Ants have crawled across } \\
\text { the sky, inspecting their possessions, looking } \\
\text { for something to eat, to feed themselves and } \\
\text { other ants. Nothing particularly interesting } \\
\text { happened in their lives. And it could not } \\
\text { happen, because these were ants. }\end{array}$} \\
\hline
\end{tabular}

(C) Ivashkevych Eduard, Stoliarenko Olha DOI (article): https://doi.org/10.32626/2227-6246.2021-53.126-148 
DOI: https://doi.org/10.32626/2227-6246.2021-53

2021. випуск 53

Pupils were offered a creative task with a given beginning (see Table 1), which had to be completed. The effective aspect of solving creative tasks by senior pupils had different expressions: overcoming problems gave schoolchildren new knowledge (semantic aspect), overcoming cognitive dissonance, due to the need to choose a certain personal position according to some text from literature, created opportunities for pupils' personal development.

The ambiguity of the conditions of this task was determined by the multiplicity of directions of mental activity of the person and the variety of pupils' answers. The latter were ranked by us by such levels:

Level 1. Pupils do not understand the content of proposed creative task to them, do not try to solve it or even to analyze it. As a rule, schoolchildren cannot understand the main idea of the problem and the tasks, formulated by the teacher, do not agree to discuss it, do not come into a contact with other senior pupils.

Level 2. Pupils only repeat the content of the teacher's creative task and focus on the formulated questions, do not try to understand or analyze the problem contained in the task, express and justify their views on the vision of the problem in order to solve it.

Level 3. Communication of pupils at this level has a clear focus on a particular literary story or a novel, which, according to senior pupils, can help solve creative task proposed to them by a teacher. Analyzing the problem, pupils compare the content of the problem with the plot of a particular literary story or a novel. In such a way the process of solving the problem became formal, fixed at the subject level of the literary layer. Pupils analyze or simply explain the choice of solutions of this problem or the proposed conclusions, correlating their opinion only with a particular story or a novel, so the process of solving the problem is not creative, and the decision can (c) Ivashkevych Eduard, Stoliarenko Olha

DOI (article): https://doi.org/10.32626/2227-6246.2021-53.126-148 
not be considered by their own, because it is based on the conclusions made in critical literature or those ones which correspond to the main idea of a story or a novel (as a rule, pupils do not express their own judgments or thoughts, but only repeat opinions from practical literature or from the text).

Level 4. The analysis of the problem situation is carried out only at the superficial level. Pupils analyze only the content of the proposed task, do not try to focus their own attention and the attention of other schoolchildren on the problems of this creative task. Therefore, the statements of pupils are purely superficial, and based on them it is impossible to draw conclusions about the problem and on this basis to identify the ways to solve the problem creatively. According to this, it is impossible to speak about the tolerant attitude to the opinions of partners of communication in the process of such a discussion, because the superficial nature of suggestions does not provide great opportunities for productive communication of senior pupils in order to solve different problems creatively.

Level 5. Pupils are actively involved into the process of discussing the problem according to a content of a creative task proposed them by the teacher or try to solve it independently, in the process of individual activity. Senior pupils analyze the problems contained in the creative task, compare their own views with the opinions of other schoolchildren, while they tried being tolerant according to the statements of their partners of communication. But at the same time senior pupils do not sufficiently substantiate their own positions and, therefore, do not try to develop themselves in order to find further creative solutions. Thus, the process of solving the problems is limited only by analyzing its content and comparing the opinions expressed by senior pupils.

Level 6. Pupils explain and try to justify their own views according to proposed to them creative tasks, while actively cooperating with partners of communication, tried to be tole-

(C) Ivashkevych Eduard, Stoliarenko Olha DOI (article): https://doi.org/10.32626/2227-6246.2021-53.126-148 
DOI: https://doi.org/10.32626/2227-6246.2021-53

2021. випуск 53

rant to other opinions and according to the proposed means of solving different problems. Senior pupils, analyzing their own statements and comparing them with the judgments of partners of communication, do not bring the process of solving a creative problem to a logical conclusion.

Level 7. Pupils clearly justify their positions, analyzing their own points of view and statements, comparing them with the opinions of partners of communication. At the same time, schoolchildren show tolerance towards other pupils, even completely opposite statements and means of solving creative tasks by the last ones. Pupils actively defended their positions, logically explaining and justifying them. Schoolchildren do not object to cooperation with partners of communication in the process of solving problematic creative tasks within small micro-groups and the whole class.

It should also be taken into account that $87 \%$ of pupils in group 1 and $83 \%$ of group 2 did not perceive the situation as problematic one and only after a few explanations from the teacher made their own attempts to continue the task. The percentage distribution of responses of senior pupils by their types is shown in Table 2.

Table 2

Distribution of answers of senior pupils when they are solving a creative problem (in \%)

\begin{tabular}{|c|c|c|}
\hline \multirow{2}{*}{ A type of the answer } & \multicolumn{2}{|c|}{ Percentage distribution of answers } \\
\cline { 2 - 3 } & group 1 & group 2 \\
\hline Level 1 & 31 & 20 \\
Level 2 & 28 & 21 \\
Level 3 & 11 & 23 \\
Level 4 & 16 & 21 \\
Level 5 & 9 & 7 \\
Level 6 & 2 & 8 \\
Level 7 & 3 & 0 \\
\hline
\end{tabular}

(C) Ivashkevych Eduard, Stoliarenko Olha

DOI (article): https://doi.org/10.32626/2227-6246.2021-53.126-148 
DOI: https://doi.org/10.32626/2227-6246.2021-53

2021. випуск 53

As it was shown in Table 2 , the vast majority of senior pupils in both Group 1 and Group 2 did not succeed in solving this problem because they did not understand the meaning of the problem situation, did not understand its content, so attempts to complete the task did not lead to a positive result. Senior pupils (despite various programs in the study of World Literature) can not be creative in finding their own solutions, take unconscious steps, which although have a certain direction, but do not contribute to the logical completion of the problem proposed by the teacher.

To get the optimization in the effectiveness of group activity we tried to make some group activities' improvement.

\section{Step 1. Regrouping.}

We started to organize pupils in groups which are different from usual ones by dividing them by the method of randomization (for example, by using a box with pieces of colorful papers: those pupils with papers which are matched make a pair), and not by the place where they are sitting.

As the result, pupils stopped complaining so much about their partners of communication and opportunities to work with different partner every time.

During this stage of the lesson we noticed that some of students are shy or they don't know each other well, feel themselves uncomfortable working together. To solve this problems we asked for advice from some more experienced teacher and tried to start group activity with a quick ice-breaker, such as:

1. Answering a question: "Would you rather...?»;

2. Answering funny questions;

3. Trying to say their name backwards;

4. Sharing their favorite animal, app, to sing a song, to show a «movie», food, dessert, etc.;

5. Playing a quick round (1-2 minutes) of word associations.

These are not important activities from the first sight, but they help partners of communication to work better together. 
DOI: https://doi.org/10.32626/2227-6246.2021-53

2021. випуск 53

Step 2. More clear tasks.

To make sure that all the pupils would know exactly what they need to do. After explaining the task orally we also wrote the task on the board for the students to be able to read it during the whole period of presenting the activities. We also tried to ask one person of each group to explain what they are going to do before they started their activity.

After this pupils will concentrate their attention on the performing each of the task and they don't need to spend additional time on asking questions about this task.

\section{Step 3. Motivating pupils.}

1) Measurable results.

We formulated more practical tasks which required some visible results, for example instead of "discuss the problem» we gave the task «to think of 5-7 ways to solve the problem and to describe them on a piece of paper». Such kind of task encouraged pupils to concentrate more attention on performing the task and spend less time talking about irrelevant things.

2) Clear intentions.

In order to help pupils to understand why group activity is important we started to explain pupils what they are expected to learn during the activity.

Understanding of the reason what for they are doing each task and how it will effect their language learning made pupils much more motivated.

Another drawback of group activity is that pupils who are focused, engaged, and working collaboratively can seem noisy from time to time. Teachers should have clear expectations and assign schoolchildren some roles and responsibilities. There will still be noisy at the lesson, but this will be the positive noise of pupils completing meaningful learning tasks. In addition, some groups will experience conflict and disagreement with their members. Teachers can show different ways to deal with conflicts and to help pupils learn to manage themselves. (c) Ivashkevych Eduard, Stoliarenko Olha

DOI (article): https://doi.org/10.32626/2227-6246.2021-53.126-148 
Learning in groups explicates a real-life learning experience of pupils being outside the classroom as well.

Group activity takes a lot of time and planning. However, even in large groups, if there is a clear instruction, group activity can be an extremely successful opportunity for engaging pupils in the classroom and helping them to remember key concepts of the information having been studied.

Organization is one of the most important features of effective group activity. For group activity to run smoothly the teacher has to plan the lesson carefully.

Firstly, teachers should structure each lesson to help students understand the elements of group activity. The lesson should have four key components:

1) a respectful and safe attitude of a teacher to learners;

2) communicative skills for group activity;

3) strategies for dealing with conflicts;

4) classroom expectations for working in groups.

If we have the aim for group activity to be effective, students need to understand the purpose and goals of group tasks and the criteria to reach the success. Teachers should also plan tasks that promote learning to be meaningful and authentic. Small groups might practice for making a presentation for the whole task. Each pupil can create a piece of information for their micro-group that helps completely to learn tasks. Group members will discuss different ideas related to a topic and decide according to this topic three main ideas.

Micro-groups can be made in different ways for different purposes. Sometimes a teacher might distribute pupils into micro-groups based on learner's differences. At other times, the teacher might allow the students to organize their own groups. There are no set rules, but here are some general questions that have to be considered about pupils' regrouping. These questions are below.

How many pupils do we need for group activities? The research on this topic varies. Some experts recommend small (C) Ivashkevych Eduard, Stoliarenko Olha DOI (article): https://doi.org/10.32626/2227-6246.2021-53.126-148 
DOI: https://doi.org/10.32626/2227-6246.2021-53

2021. випуск 53

groups with four or five pupils. Others say that somewhere micro-groups with members between three and seven schoolchildren are ideal. The number of students depends on the type of content and the learning objectives of the task. In addition, the number of students does not need to be the same in all groups. The teacher may decide that different students would benefit from interacting in different ways. Large or small groups should provide equal opportunities for success among the members. This means that everyone has the chance to contribute and demonstrate knowledge and abilities.

Is the micro-group homogeneous or heterogeneous? In other words, should the group members be the same in some situations or different? Again, this will be based on the learning setting and on the learners themselves. The choice often depends on the objective of the lesson. Some types of tasks work well when the students have different characteristics different genders, abilities, skill levels, nationalities, and/or personalities. For example, a problem-solution activity benefits from different viewpoints. Other tasks might be more successful with group members who have similar characteristics. For a discussion activity it is better to put the quieter students together. They will feel more comfortable and have more opportunities to speak. Sometimes random grouping can also be useful. This can quickly be done by having pupils count off to the desired number of groups or even by using an online team generator.

Is the micro-group fixed or flexible? Teachers can decide if they want the groups to have the same members over a period of time or change members each class or lesson that uses group activity. In fixed groups the members can develop their relationships and trust themselves to reach benefit learning. On the other hand, using flexible groups allows pupils to get to know each other. This builds classroom community. Schoolchildren also benefit from each other's strengths and see a (C) Ivashkevych Eduard, Stoliarenko Olha

DOI (article): https://doi.org/10.32626/2227-6246.2021-53.126-148 
DOI: https://doi.org/10.32626/2227-6246.2021-53

2021. випуск 53

wide variety of perspectives. Teachers can also choose to use a combination of fixed and flexible regrouping in their classes.

Should group members have assigned roles? Some teachers like to have specific roles for members in each group. So, expectations and pupils' responsibilities are clear. Individual roles are not always necessary. For starting out, though, assigned roles can provide valuable structure for group activity. Roles can be assigned by the teacher or decided by the groups themselves. Roles can be consistent for the whole project or rotated among group members. Here are some ideas to start with for providing pupil roles:

- A Leader: he/she manages pupils' interaction in the group and keeps them on doing the tasks.

- A Scriber/Note-taker: he/she writes down the important information related to the task (fills in a chart, completes the checklist or takes notes).

- A Reporter: gives results to the whole group or shares information that he/she needs.

- A Time-keeper: makes sure that the activity is progressing at this time and with enough time to finish.

Specific roles can be based on the type of a task and the number of pupils in the groups; for example, if the monitor has a vocabulary that might also be useful or assigning someone to create some visual elements.

So, it is useful for teachers to make sure that following aspects are determined or clarified according to group activity:

- Where does the group experience fit into the overall curriculum?

- What is the overall purpose and what the learning goals are?

- Whether the learning goals are sufficiently specific, clear, worthy, realistic, and achievable?

- According to the group activities and the schedule are these activities meaningful and if there is sufficient time to accomplish the goals?

(C) Ivashkevych Eduard, Stoliarenko Olha DOI (article): https://doi.org/10.32626/2227-6246.2021-53.126-148 
DOI: https://doi.org/10.32626/2227-6246.2021-53

2021. ВиПУСК 53

- What is the planned group's size and what about mixed characteristics?

- Who are the learners - their interests, desires and learning needs?

- What resources do pupils need for the lesson?

- Do you need to provide the kind of leadership?

- What are the learners' roles and responsibilities?

- How will the decisions be made in each group?

- How will the learners be evaluated?

\section{Conclusions}

As the means of purposeful influence on the thinking abilities of pupils we consider solving cognitive tasks collected by schoolchildren into a special system.

We define thinking as the highest degree of Cognitive Activity of the person. We believe that the mental development of the child can not be analyzed separately from the mental development as a whole, from the interests of the child, his/ her feelings, from personal traits and qualities. Mental development is a complex phenomenon, which is characterized by a set of features and due to a number of reasons: the content of knowledge acquired by the child, methods of influencing the personality. Until now, there is no unambiguous definition of «mental development». We believe that «mental development» is a complex dynamic system of quantitative and qualitative changes that occur in human mental activity in the connection with age and enrichment of life experience of pupils (in accordance with the socio-historical conditions in which schoolchildren live and according to individual characteristics of pupils' thinking).

\section{Literature}

Емельянов Ю.Н. Теория формирования и практика совершенствования коммуникативной компетентности: автореф. дис. ... д-ра психол. наук: 19.00.07. Ленинград, 1991. 36 с.

C Ivashkevych Eduard, Stoliarenko Olha

DOI (article): https://doi.org/10.32626/2227-6246.2021-53.126-148 
Івашкевич Е., Гудима О. Psychological ways of the development of intercultural competence of pupils in the field of «Foreign Language Education" (according to the experience of education in foreign countries). Збірник наукових праць «Проблеми сучасної психолоziï», 2020, 49, 84-105. URL : https://doi.org/10.32626/2227-6246. 2020-49.84-105.

Куницына В.Н. Социальная компетентность и социальный интеллект: структура, функции, взаимоотношение. Санкт-Петербург : СПбТУ, 1995. C. $48-59$.

Леонтьев А.Н. Проблемы развития психики. Москва : Изд-во МГУ, $1981.584 \mathrm{c}$.

Михальчук Н., Онуфрієва Л. Psychological principles of learner's autonоту. Збірник наукових праць "Проблеми сучасної психологї̈, 2020, 49, 244-268. URL : https://doi.org/10.32626/2227-6246. 2020-49.244-268.

Южанинова А.Л. К проблеме диагностики социального интеллекта личности. Проблемы оценивания в психологии. Саратов, 1984. С. 8487.

Argyle, M., Furnham, A., \& Graham, J. Social situations. London : Cambrige University Press, 1981. $133 \mathrm{p}$.

Cantor, N.G., \& Kihlstrom, J.F. Personality and social intelligence. New York : Prentice-Hall, Inc. Englewood Cliffs, New Jersey, 1987. 420 p.

Mykhalchuk Nataliia, \& Ivashkevych Eduard. Psycholinguistic features of the development of social intelligence of the teacher. Психолінгвістика. Психолингвистика. Psycholinguistics, 2018, 23 (1), 242257. URL : https://doi.org/10.5281/zenodo.1211618.

Onufriieva, L., Chaikovska, O., Kobets, O., Pavelkiv, R., \& Melnychuk, T. Social Intelligence as a Factor of Volunteer Activities by Future Medical Workers. Journal of History Culture and Art Research, 2020, 9 (1), 84-95. URL : http://dx.doi.org/10.7596/taksad.v9i1.2536.

Zubiashvily, I., Kocharian, A., Lunov, V., Barinova, N., \& Onufriieva, L. Phenomenon of money: Social and psychological essence and functions. International Journal of Psychosocial Rehabilitation, 2020, 24 (3), 1629-1642. URL : http://dx.doi.org/10.37200/IJPR/V24I3/ PR200911.

\section{References}

Yemelianov, Yu.N. (1991). Teoriia formirovaniia i praktika sovershenstvovaniia kommunikativnoi kompetentnosti [The theory of the development and the practice of improving communicative competence]. Extended abstract of Doctor's thesis. Leningrad [in Russian].

(C) Ivashkevych Eduard, Stoliarenko Olha

DOI (article): https://doi.org/10.32626/2227-6246.2021-53.126-148 
DOI: https://doi.org/10.32626/2227-6246.2021-53

2021. ВиПУСК 53

Ivashkevych, E., \& Hudyma, O. (2019). Psychological ways of the development of intercultural competence of pupils in the field of «Foreign Language Education" (according to the experience of education in foreign countries). Zbirnyk naukovykh prats «Problemy suchasnoi psykholohii» - Collection of scientific issues "Problems of modern Psychology», 49, 84-105. Retrieved from https://doi.org/10.32626/ 2227-6246.2020-49.84-105.

Kunitsyna, V.N. (1995). Sotsialnaia kompetentnost $i$ sotsialnyi intellekt: struktura, funktsii, vzaimootnosheniie [Social competence and social intelligence: structure, functions, relationships]. Sankt-Peterburg : $\mathrm{SPbTU}$ [in Russian].

Leontiev, A.N. (1981). Problemy razvitiia psikhiki [Problems of the development of the psyche]. Moskva : Izd-vo MGU [in Russian].

Mykhalchuk, N., \& Onufriieva, L. (2020). Psychological principles of learner's autonomy. Zbirnyk naukovykh prats «Problemy suchasnoi psykholohii»-Collection of scientific issues "Problems of modern Psychology», 49, 244-268. Retrieved from https://doi.org/10.32626/22276246.2020-49.244-268.

Yuzhaninova, A.L. (1984). K probleme diagnostiki sotsialnogo intellekta lichnosti [To the problem of the diagnostics of social intelligence of the person]. Problemy otsenivaniia $v$ psikhologii - Problems of evaluation in psychology, (pp. 84-87). Saratov [in Russian].

Argyle, M., Furnham, A., \& Graham, J. (1981). Social situations. London : Cambrige University Press.

Cantor, N.G., \& Kihlstrom, J.F. (1987). Personality and social intelligence. New York : Prentice-Hall, Inc. Englewood Cliffs, New Jersey. Mykhalchuk, Nataliia, \& Ivashkevych, Eduard (2018). Psycholinguistic features of the development of social intelligence of the teacher. Psykholinhvistyka. Psikholingvistika. Psycholinguistics - Psycholinguistics. Psycholinguistics. Psycholinguistics, 23 (1), 242-257. Retrieved from https://doi.org/10.5281/zenodo.1211618.

Onufriieva, L., Chaikovska, O., Kobets, O., Pavelkiv, R., \& Melnychuk, T. (2020). Social Intelligence as a Factor of Volunteer Activities by Future Medical Workers. Journal of History Culture and Art Research, 9 (1), 84-95. Retrieved from http://dx.doi.org/10.7596/ taksad.v9i1.2536.

Zubiashvily, I., Kocharian, A., Lunov, V., Barinova, N., \& Onufriieva, L. (2020). Phenomenon of money: Social and psychological essence and functions. International Journal of Psychosocial Rehabilitation, 24 (3), 1629-1642. Retrieved from http://dx.doi.org/10.37200/ IJPR/V24I3/PR200911.

C Ivashkevych Eduard, Stoliarenko Olha

DOI (article): https://doi.org/10.32626/2227-6246.2021-53.126-148 http://journals.uran.ua/index.php/2227-6246 
DOI: https://doi.org/10.32626/2227-6246.2021-53

2021. ВИПУСК 53

Івашкевич Едуард, Столяренко Ольга. Проблема розвитку діалогічних якостей пізнавальної діяльності старшокласників у навчальному процесі закладів середньої освіти

\section{АНОТАЦІЯ}

Мета статmі - описати ефективність запропонованої системи формуючих впливів учителя на розвиток діалогічних якостей пізнавальної діяльності старшокласників, яку було визначено на основі порівняння початкового та заключного розділів, зроблених методом семантичного аналізу розв'язання учнями літературних творчих проблем.

Для розв'язання поставлених у роботі завдань використано такі теоретичні методи дослідження: категоріальний, структурно-функціональний, аналіз, систематизація, моделювання, узагальнення. Також у дослідженні нами використано емпіричні методи, такі як експеримент, із метою дослідження ефективності групових форм роботи школярів на уроках.

Результати дослідження. Показано, що аналіз проблемної ситуації здійснюється лише на поверхневому рівні розвитку діалогічних якостей пізнавальної діяльності старшокласників. Школярі аналізують лише зміст запропонованого завдання, не роблять спроби сконцентрувати власну увагу й увагу інших школярів на проблемності конкретного завдання. Тому судження школярів носять суто поверхневий характер, на їх основі не можна зробити висновки щодо проблеми та на основі цього виокремити шляхи творчого розв'язання задачі. 3 огляду на це, не можна говорити про наявність у процесі такого обговорення толерантного ставлення до думок партнерів по спілкуванню, оскільки поверхневий характер суджень не надає можливостей для організації продуктивного спілкування старшокласників із метою творчого розв'язання проблемних завдань.

Відповідно до середнього рівня розвитку діалогічних якостей пізнавальної діяльності старшокласників учні пояснюють і роблять спроби обгрунтувати власні точки зору щодо запропонованої їм для розв'язання творчої задачі, при цьому активно співпрацюють із партнерами по спілкуванню, толерантно ставляться до інших думок і до запропонованих партнерами засобів розв'язання задач. Але старшокласники, аналізуючи свої власні висловлювання та порівнюючи їх із судженнями партнерів по спілкуванню, не доводять процес розв'язання творчого завдання до логічного кінця.

(C) Ivashkevych Eduard, Stoliarenko Olha DOI (article): https://doi.org/10.32626/2227-6246.2021-53.126-148 
DOI: https://doi.org/10.32626/2227-6246.2021-53

2021. випуск 53

Ми говоримо про високий рівень розвитку діалогічних якостей пізнавальної діяльності старшокласників, коли учні чітко обгрунтовують свої позиції, аналізуючи власні точки зору та судження, порівнюючи їх із думками партнерів по спілкуванню. При цьому учні проявляють толерантність щодо інших, навіть зовсім протилежних висловлювань $і$ засобів розв'язання старшокласниками творчих завдань. Школярі активно відстоюють власні позиції, логічно пояснюючи й обгрунтовуючи їх. Старшокласники не заперечують проти співпраці з партнерами по спілкуванню в процесі розв'язання проблемних творчих завдань у межах малих мікрогруп і класу загалом.

Висновки. Доведено, що засобом цілеспрямованого впливу на мисленнєві здібності школярів ми вважаємо розв'язання школярами пізнавальних задач, унормованих у спечіальну систему.

Ми визначаємо мислення як вищий ступінь пізнання. Вважаємо, що розумовий розвиток дитини не можливо аналізувати окремо від психічного розвитку загалом, від інтересів дитини, ії відчуттів, тобто від особистісних рис і якостей. Доведено, що розумовий розвиток- че складне явище, що характеризується сукупністю рис та обумовлене низкою причин: змістом знань, які отримує дитина, методами впливу на особистість тощо. Ми вважаємо, що "розумовий розвиток» - складна динамічна система кількісних і якісних змін, що відбуваються в мисленнєвій діяльності людини у зв'язку з віком і збагаченням життєвого досвіду (відповідно до суспільно-історичних умов, у яких живе людина, й індивідуальних особливостей її мислення).

Ключові слова: діалогічні якості пізнавальної діяльності, розумовий розвиток, мисленнєві здібності, творчі завдання, прочес спілкування, продуктивне спілкування, мікрогрупи, розв'язання творчої задачі, логічний висновок.

Ивашкевич Эдуард, Столяренко Ольга. Проблема развития диалогических качеств познавательной деятельности старшеклассников в учебном процессе учреждений среднего образования

\section{АННОТАЦИЯ}

Цель статьи - описать эффрективность предложенной системы формирующих воздействий учителя на развитие диалогических качеств познавательной деятельности старшеклассников, которая была определена (c) Ivashkevych Eduard, Stoliarenko Olha

DOI (article): https://doi.org/10.32626/2227-6246.2021-53.126-148 http://journals.uran.ua/index.php/2227-6246 
DOI: https://doi.org/10.32626/2227-6246.2021-53

2021. ВИПУСК 53

на основе сравнения начального и заключительного срезов, сделанных методом семантического анализа решения учащимися литературных творческих задач.

Для решения поставленных в работе задач использованы следующие теоретические методы исследования: категориальный, структурно-функциональный, анализ, систематизация, моделирование, обобщение. Также в исследовании нами использованы эмпирические методы, такие как эксперимент, с целью исследования эффективности групповых форм работы школьников на уроках.

Результаты исследования. Мы показали, что если анализ проблемной ситуации осуществляется на поверхностном уровне развития диалогических качеств познавательной деятельности старшеклассников, то школьники анализируют только содержание предложенной задачи, не делают попытки сконцентрировать собственное внимание и внимание других школьников на проблемности данной задачи. Поэтому суждения школьников имеют сугубо поверхностный характер, на их основе нельзя сделать выводы касательно данной проблемы и на основе этого выделить пути творческого решения задачи. Учитывая это, нельзя говорить о наличии в процессе такого обсуждения толерантного отношения к мыслям партнеров по общению, поскольку поверхностный характер суждений не предоставляет возможностей для организации продуктивного общения старшеклассников с целью творческого решения проблемных задач.

Согласно среднему уровню развития диалогических качеств познавательной деятельности старшеклассников, ученики объясняют и делают попытки обосновать собственные мнения относительно предложенной им для решения творческой задачи, при этом активно сотрудничают с партнерами по общению, толерантно относятся к другим мнениям и предложенным партнерами средствам решения задач. Но старшеклассники, анализируя свои собственные высказывания и сравнивая их с суждениями партнеров по общению, не доводят процесс решения творческой задачи до логического конца.

Мы говорим о высоком уровне развития диалогических качеств познавательной деятельности старшеклассников, когда ученики четко обосновывают свои позиции, анализируя собственные точки зрения и суждения, сравнивая их с мыслями партнеров по общению. При этом ученики проявляют толерантность по отношению к другим, даже совер-

(C) Ivashkevych Eduard, Stoliarenko Olha DOI (article): https://doi.org/10.32626/2227-6246.2021-53.126-148 
DOI: https://doi.org/10.32626/2227-6246.2021-53

2021. випуск 53

шенно противоположным высказываниям и средствам решения старшеклассниками творческих задач. Школьники активно отстаивают свои позиции, логично объясняя и обосновывая их. Старшеклассники не возражают против сотрудничества с партнерами по общению в процессе решения проблемных творческих задач в рамках малых микрогрупп и целого класса.

Выводы. Доказано, что средствами иеленаправленного воздействия на мыслительные способности школьников мы считаем решение учениками познавательных задач, унормированных в специальную сисmeмy.

Мы определяем мышление как высшую степень познавания. Считаем, что умственное развитие ребенка невозможно анализировать отдельно от психического развития в целом, от интересов ребенка, его чувств, то есть от личностных черт и качеств. Доказано, что умственное развитие - это сложное явление, которое характеризуется совокупностью черт и обусловлено рядом причин: содержанием знаний, которые получает ребенок, методами воздействия на личность и др. Мы считаем, что “умственное развитие» - это сложная динамическая система количественных и качественных изменений, происходящих в мыслительной деятельности человека в связи с возрастом и обогащением жизненного опыта (в соответствии с общественно-историческими условиями, в которых живет человек, и индивидуальными особенностями его мышления).

Ключевые слова: диалогические качества познавательной деятельности, умственное развитие, мыслительные способности, творческие задачи, прочесс общения, продуктивное общение, микрогруппы, решение творческой задачи, логчческий вывод.

Original manuscript received April 19, 2021 Revised manuscript accepted May 24, 2021

(C) Ivashkevych Eduard, Stoliarenko Olha

DOI (article): https://doi.org/10.32626/2227-6246.2021-53.126-148 